\title{
Mucosal Immunity and Sublingual Immunotherapy in Respiratory Disorders
}

\author{
Nerin N. Bahceciler \\ Division of Allergy and Clinical Immunology, Pediatric Department, Near East University Hospital, Nicosia, North Cyprus, Turkey \\ Correspondence should be addressed to Nerin N. Bahceciler, nerin74@gmail.com \\ Received 25 July 2012; Accepted 25 July 2012 \\ Copyright (c) 2012 Nerin N. Bahceciler. This is an open access article distributed under the Creative Commons Attribution License, \\ which permits unrestricted use, distribution, and reproduction in any medium, provided the original work is properly cited.
}

The prevalence of allergic diseases, specially respiratory allergic diseases such as allergic rhinitis and asthma, has been increasing worldwide for the last 2 decades $[1,2]$. Although avoidance of the responsible allergen, anti-inflammatory, and symptomatic treatment modalities has shown great efficacy in the treatment of allergic respiratory disorders, cessation of pharmacotherapy usually results in recurrence of signs and symptoms, with a demand to restart the treatment.

Currently, allergen-specific immunotherapy (SIT) is the only available curative choice with the capacity of altering the natural course of allergy [3,4]. Although SIT by the subcutaneous route has been extensively used and has shown marked efficacy since its discovery, it was associated with uncommon, but severe or even fatal, systemic reactions [5]. Consequently, alternative, noninjectve allergen delivery routes have been proposed, and allergen delivery through mucosal surfaces was suggested as a possible mechanism for the induction of mucosal tolerance to allergens $[5,6]$. Local mucosal routes such as oral, nasal, bronchial, and sublingual were investigated since then, and controlled trials failed to demonstrate satisfactory clinical efficacy and/or safety of oral, nasal, and bronchial allergen application; therefore those routes have been abandoned [7-11]. Meanwhile, the efficacy and safety of SIT via the sublingual route was well documented by a number of controlled trials both in children and adults with asthma and/or rhinitis [12, 13]. Since then, sublingual immunotherapy (SLIT) in the liquid drop formulation has been tested in a large number of double-blinded, placebo-controlled studies, and those studies were included in Cochrane meta-analyses [14-16] demonstrating efficacy both in children and adults with allergic rhinitis or asthma sensitized to house dust mite or various pollens. Thereafter, orodispersible grass-pollen tablets were developed and recent well-designed, well-powered, doubleblinded, placebo-controlled studies demonstrated efficacy and safety of tablet formulation [17-20].

Some of those studies improved our understanding of the underlying immunological mechanisms in addition to the proven safety and efficacy. Recent studies demonstrated that SLIT exerts its immune-suppressive effect through the induction of Treg cytokines such as IL-10 and TGF-beta $[21,22]$. This effect starts on the uptake of allergen by oral mucosal Langerhans cells through high-affinity IgE receptors [6]. More recent studies demonstrated increase in expression of Foxp3+ cells in the sublingual mucosa, which was accompanied by the systemic immunologic response during SLIT [23].

Hereby in this issue, data on clinical implications, efficacy, compliance, monitorization of delivery, and immunological mechanisms of allergen SIT delivered by the mucosalmainly sublingual route will be presented.

Nerin N. Bahceciler

\section{References}

[1] M. I. Asher, S. Montefort, B. Björksten et al., "ISAAC phase three study group," The Lancet, vol. 368, pp. 733-743, 2006.

[2] N. Ait-Khaled, J. Odhiambo, N. Pearce et al., "Prevalence of symptoms of asthma, rhinitis and eczema in 13- to 14-yearold children in Africa: the International Study of Asthma and Allergies in Childhood Phase III," Allergy, vol. 62, no. 3, pp. 247-258, 2007.

[3] J. Bousquet, R. F. Lockey, and H. J. Malling, "Allergen immunotherapy: therapeutic vaccines for allergic diseases. WHO position paper," Allergy, vol. 53, pp. 1-42, 1998.

[4] L. B. Bacharier, A. Boner, K. H. Carlsen, P. A. Eigenmann, T. Frischer, and M. Götz, "Diagnosis and treatment of asthma in 
childhood: a PRACTALL consensus report," Allergy, vol. 63, no. 5, p. 630, 2008.

[5] G. Roberts, C. Hurley, V. Turcanu, and G. Lack, "Grass pollen immunotherapy as an effective therapy for childhood seasonal allergic asthma," Journal of Allergy and Clinical Immunology, vol. 117, no. 2, pp. 263-268, 2006.

[6] N. N. Bahceciler and N. Cobanoglu, "Subcutaneous versus sublingual immunotherapy for allergic rhinitis and/or asthma," Immunotherapy, vol. 3, no. 6, pp. 747-756, 2011.

[7] P. W. Welsh, E. M. Zimmermann, and J. W. Yunginger, "Preseasonal intranasal immunotherapy with nebulized short ragweed extract," Journal of Allergy and Clinical Immunology, vol. 67, no. 3, pp. 237-242, 1981.

[8] J. W. Georgitis, R. E. Reisman, and W. F. Clayton, "Local intranasal immunotherapy for grass-allergic rhinitis," Journal of Allergy and Clinical Immunology, vol. 71, no. 1, pp. 71-76, 1983.

[9] L. Andri, G. Senna, C. Betteli, S. Givanni, G. Andri, and P. Falagiani, "Local nasal immunotherapy for Dermatophagoides-induced rhinitis: efficacy of a powder extract," Journal of Allergy and Clinical Immunology, vol. 91, no. 5, pp. 987-996, 1993.

[10] G. D'Amato, G. Lobefalo, G. Liccardi, and M. Cazzola, "A double-blind, placebo-controlled trial of local nasal immunotherapy in allergic rhinitis to Parietaura pollen," Clinical and Experimental Allergy, vol. 25, no. 2, pp. 141-148, 1995.

[11] F. Marcucci, L. G. Sensi, C. Caffarelli et al., "Low-dose local nasal immunotherapy in children with perennial allergic rhinitis due to Dermatophagoides," Allergy, vol. 57, no. 1, pp. 23-28, 2002.

[12] D. R. Wilson, M. T. Lima, and S. R. Durham, "Sublingual immunotherapy for allergic rhinitis: systematic review and meta-analysis," Allergy, vol. 60, no. 1, pp. 4-12, 2005.

[13] N. N. Bahçeciler, U. Işik, I. B. Barlan, and M. M. Başaran, "Efficacy of sublingual immunotherapy in children with asthma and rhinitis: a double-blind, placebo-controlled study," Pediatric Pulmonology, vol. 32, no. 1, pp. 49-55, 2001.

[14] M. Penagos, E. Compalati, F. Tarantini et al., "Efficacy of sublingual immunotherapy in the treatment of allergic rhinitis in pediatric patients 3 to 18 years of age: a meta-analysis of randomized, placebo-controlled, double-blind trials," Annals of Allergy, Asthma and Immunology, vol. 97, no. 2, pp. 141$148,2006$.

[15] M. Penagos, G. Passalacqua, E. Compalati et al., "Metaanalysis of the efficacy of sublingual immunotherapy in the treatment of allergic asthma in pediatric patients, 3 to 18 years of age," Chest, vol. 133, no. 3, pp. 599-609, 2008.

[16] Z. Calamita, H. Saconato, A. B. Pelá, and A. N. Atallah, "Efficacy of sublingual immunotherapy in asthma: systematic review of randomized-clinical trials using the Cochrane Collaboration method," Allergy, vol. 61, no. 10, pp. 1162-1172, 2006.

[17] C. K. Niu, W. Y. Chen, J. L. Huang, K. H. Lue, and J. Y. Wang, "Efficacy of sublingual immunotherapy with highdose mite extracts in asthma: a multi-center, double-blind, randomized, and placebo-controlled study in Taiwan," Respiratory Medicine, vol. 100, no. 8, pp. 1374-1383, 2006.

[18] K. H. Lue, Y. H. Lin, H. L. Sun, K. H. Lu, J. C. Hsieh, and M. C. Chou, "Clinical and immunologic effects of sublingual immunotherapy in asthmatic children sensitized to mites: a double-blind, randomized, placebo-controlled study," Pediatric Allergy and Immunology, vol. 17, no. 6, pp. 408-415, 2006.
[19] N. Pham-Thi, P. Scheinmann, R. Fadel et al., "Assessment of sublingual immunotherapy efficacy in children with house dust mite-induced allergic asthma optimally controlled by pharmacologic treatment and mite-avoidance measures," Pediatric Allergy and Immunology, vol. 18, no. 1, pp. 47-57, 2007.

[20] I. Stelmach, J. Kaczmarek-Woźniak, P. Majak, M. OlszowiecChlebna, and J. Jerzynska, "Efficacy and safety of high-doses sublingual immunotherapy in ultra-rush scheme in children allergic to grass pollen," Clinical and Experimental Allergy, vol. 39, no. 3, pp. 401-408, 2009.

[21] B. Bohle, T. Kinaciyan, M. Gerstmayr, A. Radakovics, B. JahnSchmid, and C. Ebner, "Sublingual immunotherapy induces IL-10-producing $\mathrm{T}$ regulatory cells, allergen-specific T-cell tolerance, and immune deviation," Journal of Allergy and Clinical Immunology, vol. 120, no. 3, pp. 707-713, 2007.

[22] R. E. O’Hehir, L. M. Gardner, M. P. de Leon et al., "House dust mite sublingual immunotherapy: the role for transforming growth factor- $\beta$ and functional regulatory T cells," American Journal of Respiratory and Critical Care Medicine, vol. 180, no. 10, pp. 936-947, 2009.

[23] G. W. Scadding, M. H. Shamji, M. R. Jacobson et al., "Sublingual grass pollen immunotherapy is associated with increases in sublingual Foxp3-expressing cells and elevated allergenspecific immunoglobulin G4, immunoglobulin A and serum inhibitory activity for immunoglobulin E-facilitated allergen binding to B cells," Clinical and Experimental Allergy, vol. 40, no. 4, pp. 598-606, 2010. 


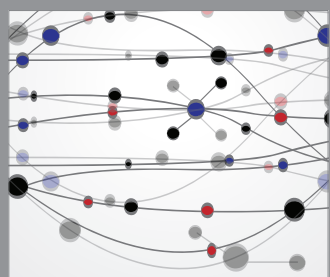

The Scientific World Journal
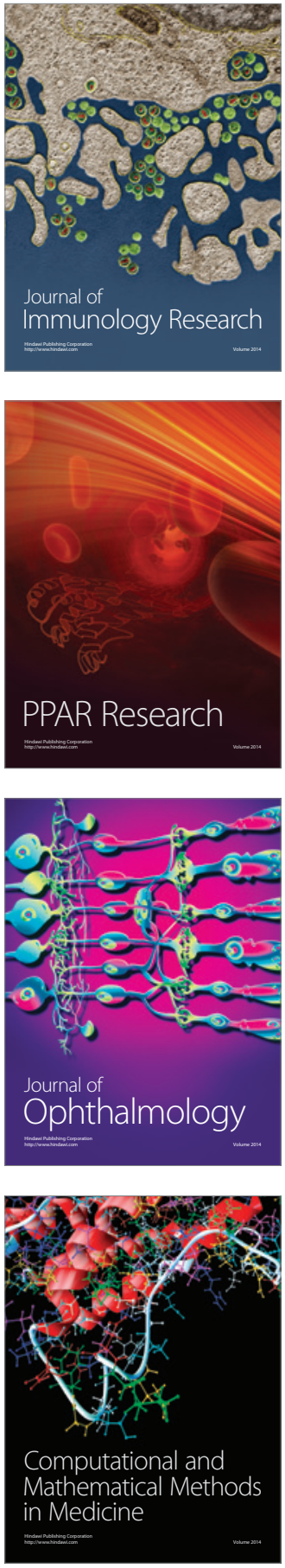

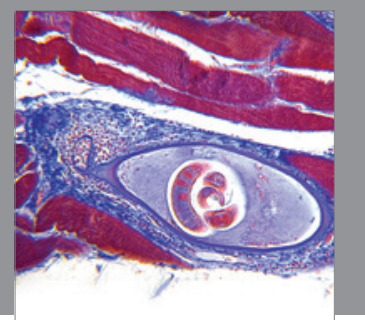

Gastroenterology

Research and Practice
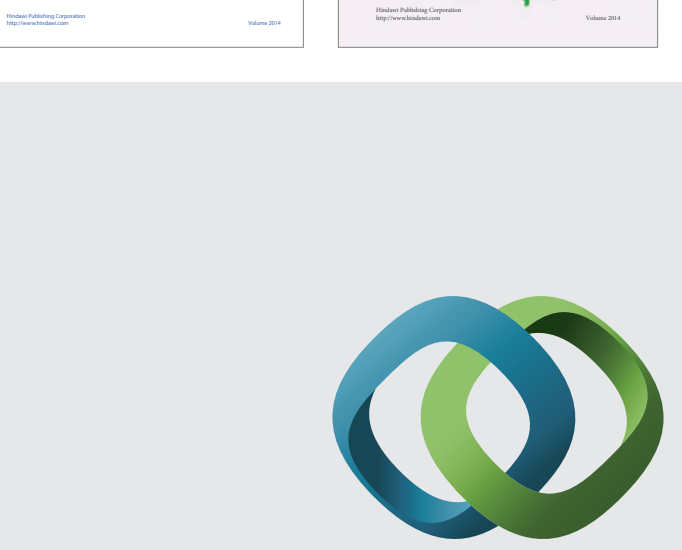

\section{Hindawi}

Submit your manuscripts at

http://www.hindawi.com
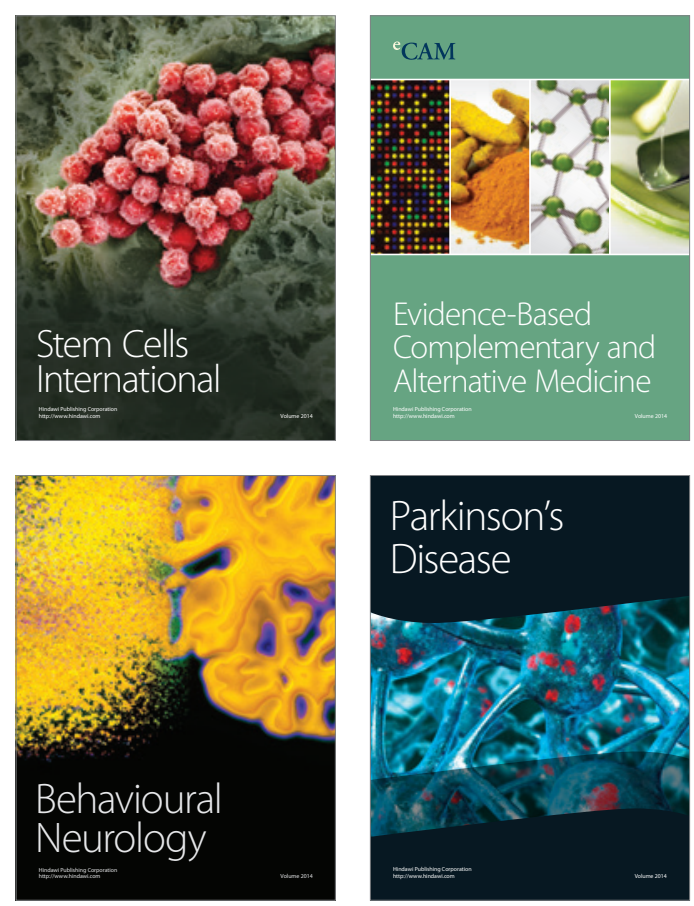

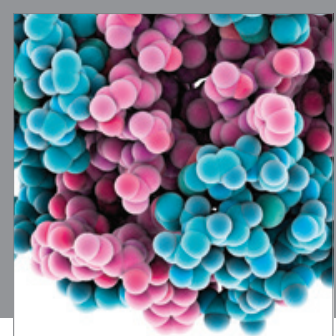

Journal of
Diabetes Research

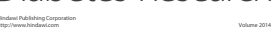

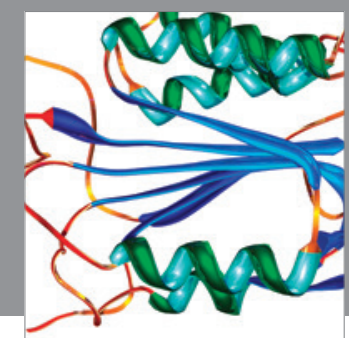

Disease Markers
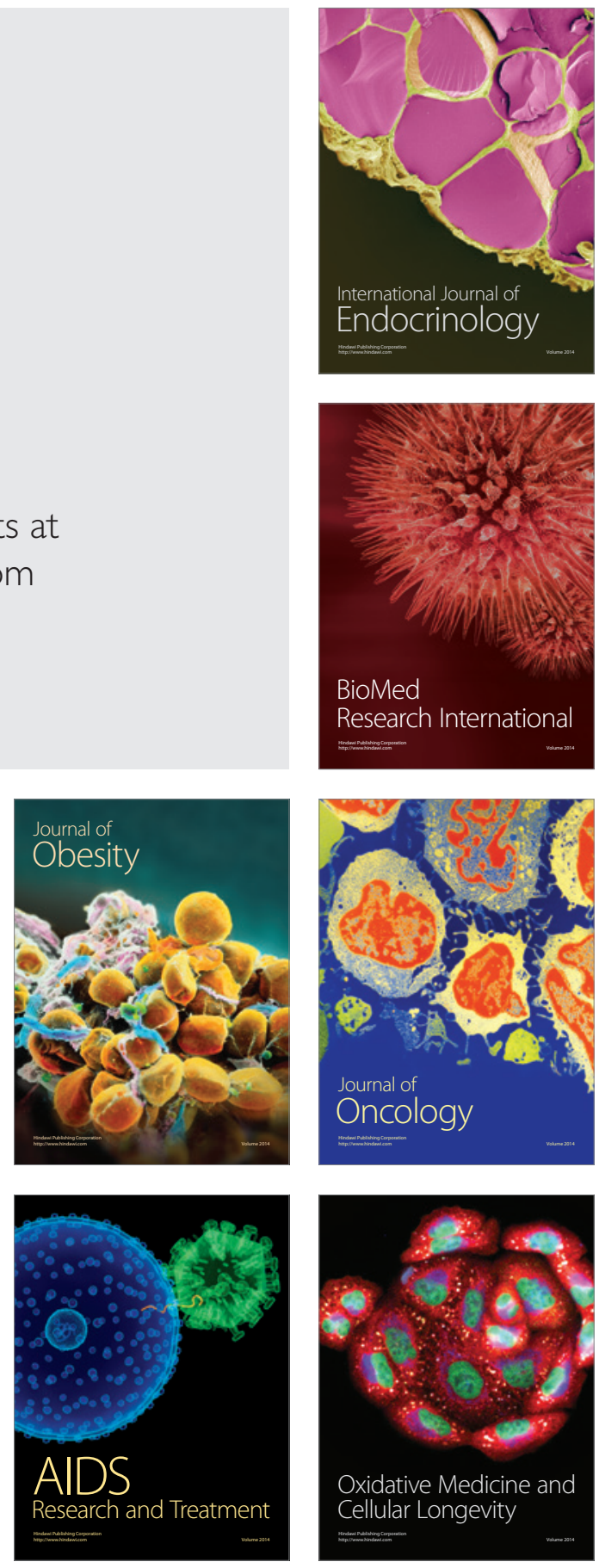